International Journal of Advanced Biological and Biomedical Research Available online at http:www.ijabbr.com

Volume 8, Issue 3 (2020) pp. 314-320

DOI: 10.33945/SAMI/IJABBR.2020.3.9

Original Article

\title{
Responses of Multiple Generations of Spodoptera Littoralis Feeding on Gossypol
}

\section{Seham Mansour Ismail*}

Insect Population Toxicology Department, Central Agricultural Pesticides Laboratory, Agriculture Research Center, Dokki, Giza, Egypt

*Corresponding Author E-mail: Seham.Ismail@arc.Sci.eg

Received: 23 December 2019, Revised: 22 February 2020, Accepted: 29 Feruary 2020

\begin{abstract}
This investigation was set to determine responses of S. littoralis through different developmental stages and generations to secondary metabolic compound presumably gossypol. Gossypol did not significantly show antifeedant except with high concentration $1.7 \%$ gossypol in the diet) that gave 10.6, 21.9 , and $46.8 \%$ for three generations, respectively. Significantly longer larval life-spans were observed in S. littoralis on a high concentration of gossypol compared with those fed on low concentrations. The larval and pupal weight of the third generation was significantly lower than that of the previous two generations as latent effects on survived larvae significantly lower fecundity was found in the second and third generations. A significantly lower relative growth rate was observed in the three successive generations. Generally, the efficiency of gossypol was significantly higher in the second and third generations. Gossypol significantly affected growth and development, suggesting that diet-gossypol efficiency was different based on concentration and generation. This study will shed some light on the possibility of controlling S. littoralis by gossypol through the sequence of alternative spraying programs.
\end{abstract}

Key words: Development, Gossypol, Spodoptera littoralis

\section{Introduction}

Secondary metabolic compounds of plants are an important biochemical basis for plant resistance to insects. Using plant resistance to insects is a major method for controlling insect pests in modern integrated pest management (Cai et al., 2004; Wu et al., 2007). Cotton plants are one of the most important cash crops that play a key role in the Egyptian agricultural economy. Cotton plants, especially the seed, are a rich source of gossypol. Gossypol produced by cottonseed (a by-product) is one of the most important toxic chemicals to herbivorous insects. It is a major source of modern biological insecticide, which is considered one of the key insect resistance mechanisms.

Gossypol, a yellow polyphenolic pigment, contains in the pigment glands of some cotton varieties and exhibits antibiosis against a number of phytophagous insects. In addition to gossypol, several other toxic terpenoids (generally referred to as terpenoid 
aldehydes) are found, including $\rho$-hemigossypolone $\rho$-hemigossypolone-6-methyl ether, heliocide $\mathrm{H}_{1}$, heliocide $\mathrm{H}_{2}$, heliocide $\mathrm{H}_{3}$, heliocide $\mathrm{H}_{4}$, heliocide $\mathrm{B}_{1}$, heliocide $\mathrm{B}_{2}$, heliocide $\mathrm{B}_{3}$, and heliocide $\mathrm{B}_{4}$ (Wu et al., 2010).

Cotton leafworm (Spodoptera littoralis Boisduval) is an important pest of numerous crops, and is considered as one of the most serious and destructive phytophagous pests of cotton cause economic damage in Egypt, causing more damage on glandless cotton in the field. Indeed, S. littoralis is known to infest more than 112 plants belonging to 44 families in a broad geographical area of the world (Meng et al., 2018). Intensive application of broad-spectrum insecticides has given rise to S. littoralis populations resistant to conventional insecticides, so these insecticides fail to adequately control S. littoralis. The development of resistance to several insecticides in S. littoralis prompted an interest in alternative methods of control (Haijing et al., 2017).

Plant secondary metabolic compounds are an important method for insect pest control. This study focused on the effect of different gossypol levels incorporated in the diet on the growth and development of S. littoralis was over three consecutive generations.

\section{Experimental}

\section{Materials and methods}

\section{Stock colony}

Insects were obtained from a colony of the cotton leafworm Spodoptera littoralis Boisduval (Lepidoptera: Noctuidae) was used for toxicity assay. This strain has been colonized for many years in the Department of Insect Population Toxicology, Central Agricultural Pesticides Laboratory, Agriculture Research Center, Dokki, Giza, Egypt, without exposure to any pesticides. The colony was kept at a temperature of $25 \pm 2{ }^{\circ} \mathrm{C}$, $\approx 70 \% \mathrm{RH}$, and a 16: $8 \mathrm{~L}$ : D photoperiod.

\section{Terpenoid aldehydes extraction and purification}

Terpenoid aldehydes were extracted and purified according to (Boatner, 1948) after soaking cottonseeds (Giza 89) in tap water for $12 \mathrm{hrs}$ at room temperature. It was done for softening of seed hull and facilitating its removal. Hull-free kernels were left to dry at room temperature. Insoluble terpenoid was collected and dried at $80{ }^{\circ} \mathrm{C}$ for $8 \mathrm{hrs}$. The melting point was determined as a criterion of purity, according to (A.O.A.C., 1984), and it was found to be $185^{\circ} \mathrm{C}$.

\section{Effect of gossypol on S. littoralis biometrics}

Newly molted second larvae of S. littoralis were continuously fed the artificial diet containing different concentrations of gossypol were tested (Meisner et al., 1978). Five concentrations of gossypol were tested. Concentrations were prepared and mixed with the diet during its preparation. The untreated diet was provided to control. Larvae (30 per each concentration) were placed in Petri dishes (9 $\mathrm{cm}$ in diameter). The tests were conducted in triplicate. Larvae mortality was scored; if no movement was observed, larvae considered dead. Weight gain of larvae was assayed on day 10 of feeding. Growth inhibition (\%) was determined on day 10 of feeding. The percentage of antifeedant activity was determined after 10 days of feeding by the formula of Abivardi and Benz 
(1984). The effect of gossypol on some physiological and biological aspects of the $2^{\text {nd }}$ larval instar of S. littoralis were recorded for three consecutive generations.

\section{Statistical analysis}

The data were statistically analyzed separately for each experiment. They were subjected to analysis of variance (ANOVA) using SPSS 12.0 software (Statistical Package for Social Sciences, USA). Mean values were compared using Duncan's multiple range test (1955).

\section{Results}

\section{Insecticidal activity of gossypol on growth and development of S. littoralis larvae}

The direct effects of adding gossypol to the diet on the growth and development of S. littoralis are presented in Tables 1-3. The results show that gossypol has an adverse effect on the growth and development of S. littoralis. Larval and pupal weights dramatically decreased with an increasing concentration of the gossypol in the second and third generations than in the first generation. The results presented in Table (1) revealed that the larvae fed on the treated diet with a concentration of $1.7 \%$ gossypol in the diet showed little growth, and the larvae were very small compared to the control. The weight gain averages on this treatment were 302, 200, and $44 \mathrm{mg} / \mathrm{larva}$ for three generations, respectively $(19.89,40.64$, and $79.44 \%$ growth inhibition, respectively) compared to 377, 336.9, and $214 \mathrm{mg} /$ larva in control, respectively. Moreover, the antifeedant activity indicated that a concentration of $1.7 \%$ gossypol in the diet was the highest in inhibitors of feeding recording 10.6, 21.9, and $46.8 \%$ for three generations, respectively. As shown in Table 2, it was clear that the prolongation in larval duration was significantly achieved with treatment $1.7 \%$ gossypol in the diet where the period of larval stage recorded in the first-generation (16.5 days), second-generation (19 days) and third-generation (24.5 days) compared to the control one. On the contrary, pupal decreased duration without significant differences among them. As shown in Table 2, the concentration of $1.5 \%$ gossypol in the diet significantly affect pupal weight were 295, 269, and $137 \mathrm{mg} / \mathrm{pupa}$, respectively, for three generations compared to the control (310, 308, and $300 \mathrm{mg} /$ pupa respectively). However, the pupal period did not increase significantly compared with that of the control one. With respect to the latent effects, the data in Table 3 indicated that the third generation was the most effective recording (50.3 and 150\%) compared to control (97 and 307\%), to percentages of adult emergence and eggs hatchability, respectively. The results indicated that second and third generations had noticeably decreased the mean numbers of eggs laid by the adult female (fecundity). Also, eggs hatchability (fertility) significantly reduced in the offspring generation after the parent second instar larvae fed on gossypol diet. Lifespan of the second and third generations was shorter than first-generation (Table 3). 
Table 1. Effect of gossypol in the diet on weight gain, growth inhibition (\%) and antifeedants activity (\%) of second-instar larvae of S. littoralis

\begin{tabular}{|c|c|c|c|}
\hline$\%$ Gossypol in the diet & $\begin{array}{c}\text { Larval mean weight } \\
\text { (mg/larvae) } \pm \mathrm{SE}\end{array}$ & Growth inhibition (\%) & Antifeedant (\% ) $\pm \mathrm{SE}$ \\
\hline & & $1^{\text {st }}$ generation & \\
\hline Control & $377^{a} \pm 1.9$ & 0.0 & 0.0 \\
\hline 0.25 & $372^{a} \pm 3.1$ & $1.33^{\mathrm{a}} \pm 1.7$ & 0.0 \\
\hline 0.5 & $370^{\mathrm{a}} \pm 2.7$ & $1.86^{\mathrm{a}} \pm 1.4$ & 0.0 \\
\hline 1.0 & $363^{b} \pm 3.2$ & $3.71^{\mathrm{a}} \pm 0.5$ & $2.7 \mathrm{a} \pm 1.9$ \\
\hline 1.5 & $335^{c} \pm 2.4$ & $11.14^{\mathrm{b}} \pm 0.8$ & $5.9^{\mathrm{a}} \pm 2.4$ \\
\hline \multirow[t]{2}{*}{1.7} & $302^{d} \pm 3.4$ & $19.89^{b} \pm 1.5$ & $10.6^{\mathrm{a}} \pm 3.4$ \\
\hline & & $2^{\text {nd }}$ generation & \\
\hline Control & $336.9^{a} \pm 3.7$ & 0.0 & 0.0 \\
\hline 0.25 & $325.6^{b} \pm 5.2$ & $3.35^{\mathrm{a}} \pm 3.3$ & 0.0 \\
\hline 0.5 & $319.3^{c} \pm 1.7$ & $5.22^{\mathrm{a}} \pm 4.7$ & $3.9^{\mathrm{a}} \pm 5.7$ \\
\hline 1.0 & $289.1^{d} \pm 3.2$ & $14.19^{b} \pm 1.5$ & $8.5^{\mathrm{a}} \pm 3.4$ \\
\hline 1.5 & $250.0^{\mathrm{e}} \pm 4.7$ & $25.79^{c} \pm 1.9$ & $13.7^{b} \pm 2.9$ \\
\hline \multirow[t]{2}{*}{1.7} & $200.0^{f} \pm 5.4$ & $40.64^{\mathrm{d}} \pm 2.4$ & $21.9^{c} \pm 3.3$ \\
\hline & & $3^{\text {rd }}$ generation & \\
\hline Control & $214^{a} \pm 5.2$ & 0.0 & 0.0 \\
\hline 0.25 & $191^{b} \pm 5.3$ & $10.75^{a} \pm 4.2$ & $11.6^{a} \pm 3.6$ \\
\hline 0.5 & $175^{c} \pm 2.4$ & $18.22^{\mathrm{a}} \pm 1.8$ & $18.8^{\mathrm{a}} \pm 4.3$ \\
\hline 1.0 & $132^{d} \pm 3.6$ & $38.32^{b} \pm 3.5$ & $27.6^{b} \pm 2.9$ \\
\hline 1.5 & $84.0^{\mathrm{e}} \pm 2.9$ & $60.75^{c} \pm 2.1$ & $32.5^{b} \pm 3.0$ \\
\hline 1.7 & $44.0^{f} \pm 3.0$ & $79.44^{d} \pm 2.6$ & $46.8^{c} \pm 5.3$ \\
\hline
\end{tabular}

Means in the same column followed by the same letter are not significantly at $\mathrm{P}<0.05$

Table 2. Life history parameters of three successive generations of S. littoralis fed on gossypol in the diet

\begin{tabular}{|c|c|c|c|c|c|}
\hline $\begin{array}{l}\text { \% Gossypol } \\
\text { in the diet }\end{array}$ & $\begin{array}{c}\text { Survival rate } \\
(\%) \pm \mathrm{SE}\end{array}$ & $\begin{array}{c}\text { Larval } \\
\text { duration } \\
\text { (days) } \pm \mathrm{SE}\end{array}$ & $\begin{array}{c}\text { Pupal mean } \\
\text { weight } \\
\text { (mg/ pupa) } \pm \mathrm{SE}\end{array}$ & $\begin{array}{l}\text { Pupal duration } \\
\text { (days) } \pm \mathrm{SE}\end{array}$ & $\begin{array}{c}\text { Pupation (\%) } \\
\pm \text { SE }\end{array}$ \\
\hline & \multicolumn{5}{|c|}{$1^{\text {st }}$ generation } \\
\hline Control & $100^{\mathrm{a}} \pm 0.0$ & $14.3^{\mathrm{b}} \pm 0.8$ & $310^{\mathrm{a} \pm} 3.1$ & $8.5^{\mathrm{a}} \pm 0.4$ & $100^{\mathrm{a}} \pm 0.0$ \\
\hline 0.25 & $99.0^{\mathrm{a}} \pm 1.7$ & $14.3^{\mathrm{b}} \pm 1.7$ & $309^{a} \pm 2.7$ & $8.4^{\mathrm{a}} \pm 1.6$ & $100^{\mathrm{a}} \pm 0.0$ \\
\hline 0.5 & $97.5^{\mathrm{a}} \pm 1.4$ & $14.3^{\mathrm{b}} \pm 1.4$ & $307^{a} \pm 3.2$ & $8.3^{a} \pm 0.7$ & $100^{\mathrm{a}} \pm 0.0$ \\
\hline 1.0 & $95.3^{\mathrm{a} \pm} 0.5$ & $14.6^{\mathrm{b}} \pm 0.5$ & $303^{a} \pm 1.9$ & $8.0^{\mathrm{a}} \pm 0.5$ & $95.1^{\mathrm{a}} \pm 0.4$ \\
\hline 1.5 & $80.0^{\mathrm{b}} \pm 0.8$ & $15.0^{\mathrm{a}} \pm 0.8$ & $295^{b} \pm 2.4$ & $7.5^{\mathrm{ab}} \pm 0.5$ & $88.8^{\mathrm{a}} \pm 1.7$ \\
\hline \multirow[t]{2}{*}{1.7} & $71.1^{\mathrm{c}} \pm 1.5$ & $16.5^{\mathrm{a}} \pm 1.5$ & $282^{\mathrm{b}} \pm 3.4$ & $7.0^{\mathrm{b}} \pm 0.8$ & $72.5^{\mathrm{b}} \pm 1.3$ \\
\hline & \multicolumn{5}{|c|}{$2^{\text {nd }}$ generation } \\
\hline Control & $100^{a} \pm 0.0$ & $14.0^{\mathrm{bc}} \pm 1.3$ & $308^{a} \pm 4.8$ & $6.3^{a} \pm 0.3$ & $96.8^{a} \pm 2.6$ \\
\hline 0.25 & $98.1^{\mathrm{a} \pm} 3.3$ & $14.5^{\mathrm{b}} \pm 1.8$ & $304^{\mathrm{a}} \pm 3.2$ & $6.0^{\mathrm{a}} \pm 0.5$ & $92.5^{\mathrm{a}} \pm 2.4$ \\
\hline 0.5 & $93.3^{\mathrm{a}} \pm 4.7$ & $15.0^{\mathrm{b}} \pm 2.3$ & $299 \mathrm{a} \pm 5.7$ & $5.8^{\mathrm{ab}} \pm 0.7$ & $90.0^{\mathrm{a}} \pm 1.3$ \\
\hline 1.0 & $88.4^{\mathrm{a}} \pm 1.5$ & $15.5^{b} \pm 1.9$ & $289^{b} \pm 3.4$ & $5.2^{\mathrm{b}} \pm 0.4$ & $87.2^{\mathrm{a}} \pm 2.2$ \\
\hline 1.5 & $61.1^{\mathrm{b}} \pm 1.9$ & $16.5^{b} \pm 1.7$ & $269^{c} \pm 2.9$ & $3.9^{c} \pm 0.5$ & $82.4^{\mathrm{ab}} \pm 3.4$ \\
\hline \multirow[t]{2}{*}{1.7} & $50.0^{c} \pm 2.4$ & $19.0^{\mathrm{a}} \pm 1.5$ & $246^{\mathrm{d} \pm} \pm 3.3$ & $3.3^{c} \pm 0.3$ & $74.3^{c} \pm 2.9$ \\
\hline & \multicolumn{5}{|c|}{$3^{\text {rd }}$ generation } \\
\hline Control & $100^{\mathrm{a}} \pm 0.0$ & $14.0^{\mathrm{cd}} \pm 1.3$ & $300^{\mathrm{a}} \pm 4.1$ & $6.6^{a} \pm 0.6$ & $98.1^{\mathrm{a}} \pm 3.5$ \\
\hline 0.25 & $96.3^{\mathrm{a} \pm} 4.2$ & $14.5^{\mathrm{c}} \pm 1.4$ & $282^{\mathrm{a}} \pm 3.6$ & $6.0^{a} \pm 0.3$ & $88.7 \mathrm{a} \pm 2.1$ \\
\hline 0.5 & $91.5^{\mathrm{a}} \pm 1.8$ & $15.0^{c} \pm 1.7$ & $221^{b} \pm 4.3$ & $5.5^{\mathrm{a}} \pm 0.4$ & $82.1^{\mathrm{ab}} \pm 4.2$ \\
\hline 1.0 & $80.6^{b} \pm 3.5$ & $17.0^{\mathrm{b}} \pm 1.5$ & $151^{c} \pm 2.9$ & $4.8^{\mathrm{ab}} \pm 0.3$ & $72.5^{c} \pm 2.6$ \\
\hline 1.5 & $53.5^{c} \pm 2.1$ & $20.5^{\mathrm{a}} \pm 1.8$ & $137^{\mathrm{d}} \pm 3.0$ & $4.0^{\mathrm{b}} \pm 0.4$ & $68.2^{c} \pm 1.8$ \\
\hline 1.7 & $30.9^{d} \pm 2.6$ & $24.5^{\mathrm{a}} \pm 1.5$ & $109 \mathrm{e} \pm 5.3$ & $3.0^{c} \pm 0.5$ & $62.6^{c} \pm 2.9$ \\
\hline
\end{tabular}

Means in the same column followed by the same letter are not significantly at $\mathrm{P}<0.05$ 
Table 3. Effect of gossypol in the diet adult emergence, adult fecundity, fertility and life span of S. littoralis

\begin{tabular}{|c|c|c|c|c|}
\hline $\begin{array}{l}\text { \% Gossypol in } \\
\text { the diet }\end{array}$ & $\begin{array}{c}\text { Adult } \\
\text { emergence } \\
(\%) \pm \mathrm{SE}\end{array}$ & $\begin{array}{l}\text { Fecundity (No. eggs } \\
\text { laid/ female) } \pm \mathrm{SE}\end{array}$ & $\begin{array}{c}\text { Fertility } \\
\text { (percentage of egg } \\
\text { hatch) } \pm \text { SE }\end{array}$ & $\begin{array}{c}\text { Life span (days) } \\
\pm \mathrm{SE}\end{array}$ \\
\hline & \multicolumn{4}{|c|}{ 1st generation } \\
\hline Control & $97.0^{\mathrm{a} \pm 0.5}$ & $334^{\mathrm{a}} \pm 1.9$ & $337^{a} \pm 0.8$ & $30.0^{\mathrm{a}} \pm 0.4$ \\
\hline 0.25 & $95.6^{\mathrm{a}} \pm 1.7$ & $330^{\mathrm{a}} \pm 3.1$ & $325^{b} \pm 1.7$ & $29.0^{a} \pm 1.6$ \\
\hline 0.5 & $90.0^{\mathrm{a}} \pm 1.2$ & $327 \mathrm{a} \pm 2.7$ & $313^{c} \pm 1.4$ & $28.0^{a} \pm 0.7$ \\
\hline 1.0 & $87.2^{\mathrm{a} \pm} 1.2$ & $317 \mathrm{ab} \pm 3.2$ & $300^{\mathrm{cd}} \pm 0.5$ & $27.0^{a} \pm 0.5$ \\
\hline 1.5 & $82.4^{\mathrm{ab} \pm} 1.6$ & $291^{c} \pm 2.4$ & $257 \mathrm{e} \pm 0.8$ & $25.0^{a} \pm 0.5$ \\
\hline \multirow[t]{2}{*}{1.7} & $74.3^{\mathrm{b}} \pm 1.3$ & $277^{\mathrm{d}} \pm 3.4$ & $212^{\mathrm{f}} \pm 1.5$ & $23.0^{\mathrm{b}} \pm 0.8$ \\
\hline & \multicolumn{4}{|c|}{ 2nd generation } \\
\hline Control & $96.3^{\mathrm{a} \pm 1.4}$ & $323^{a} \pm 3.4$ & $315^{\mathrm{a}} \pm 2.1$ & $28.0^{a} \pm 0.2$ \\
\hline 0.25 & $90.4^{\mathrm{a}} \pm 1.5$ & $313^{\mathrm{b}} \pm 3.1$ & $301^{\mathrm{b}} \pm 4.2$ & $27.0^{\mathrm{a}} \pm 2.3$ \\
\hline 0.5 & $88.1^{\mathrm{a} \pm}+1.9$ & $305^{c} \pm 1.8$ & $289^{c} \pm 2.9$ & $26.0^{\mathrm{a} \pm 2.1}$ \\
\hline 1.0 & $85.7 \mathrm{a} \pm 2.7$ & $293^{\mathrm{d}} \pm 2.1$ & $274^{\mathrm{d}} \pm 3.5$ & $24.8^{\mathrm{b}} \pm 1.9$ \\
\hline 1.5 & $70.5^{b} \pm 3.1$ & $265^{e} \pm 3.5$ & $229^{\mathrm{e}} \pm 2.3$ & $22.0^{\mathrm{b}} \pm 2.4$ \\
\hline \multirow[t]{2}{*}{1.7} & $65.3^{\mathrm{b}} \pm 2.4$ & $241^{\mathrm{f}} \pm 2.6$ & $174^{\mathrm{f}} \pm 1.8$ & $19.0^{b} \pm 1.5$ \\
\hline & \multicolumn{4}{|c|}{$3^{\text {rd }}$ generation } \\
\hline Control & $97.0^{\mathrm{a}} \pm 1.5$ & $316^{\mathrm{a}} \pm 3.2$ & $307^{a} \pm 2.7$ & $33.0^{\mathrm{a}} \pm 2.6$ \\
\hline 0.25 & $83.6^{\mathrm{ab}} \pm 2.4$ & $302^{\mathrm{b}} \pm 5.2$ & $287^{b} \pm 1.9$ & $31.0^{\mathrm{a}} \pm 1.2$ \\
\hline 0.5 & $81.1^{\mathrm{b}} \pm 2.1$ & $292^{c} \pm 1.9$ & $274^{c} \pm 3.0$ & $29.0^{\mathrm{a} \pm} 1.7$ \\
\hline 1.0 & $77.2^{\mathrm{b}} \pm 1.4$ & $278^{\mathrm{d}} \pm 4.3$ & $256^{\mathrm{d}} \pm 2.4$ & $26.0^{\mathrm{ab}} \pm 1.8$ \\
\hline 1.5 & $61.2^{c} \pm 1.6$ & $247 \mathrm{e} \pm 2.9$ & $208^{e} \pm 3.2$ & $23.0^{\mathrm{b}} \pm 1.5$ \\
\hline 1.7 & $50.3^{\mathrm{d}} \pm 0.7$ & $220^{f} \pm 5.3$ & $150^{f} \pm 3.4$ & $18.0^{\mathrm{b}} \pm 1.4$ \\
\hline
\end{tabular}

Means in the same column followed by the same letter are not significantly at $\mathrm{P}<0.05$

\section{Discussion}

Most of the published studies have focused on responses of insects to gossypol in short-term experiments. Combining short and long-term experiment findings can provide a clearer picture of insect population dynamics in response to gossypol. Based on the results, the direct negative effects of secondary metabolic plant compounds (presumable gossypol in this study) were observed on the growth and development of Spodoptera littoralis fed on the high gossypol concentration, compared with those fed on the low gossypol concentration through three successive generations. Also, the results reported that the growth and development only significantly development were only significantly decreased in the second and third generations compared with the first-generation; it is likely due to the cumulative effects of gossypol on three successive generations. Generally, there was a high correlation between the concentration of the gossypol in die and its effects on growth and development. This was a reflection of the larvae which died before pupation. The effect of diet-gossypol on the third generation significantly was higher than that of the previous two generations on S. littoralis stages. Data indicate the gossypol incorporated in a diet, decreased the larval and pupal weights of S. littoralis. The data showed that the accumulative effect is quite clear and is in a good agreement with the finding of (Meisner et al., 1978; Kay et al., 1979). They found that the incorporation of gossypol whether applied topically or into the food media, suppressed the larval weight. Also, (Du et al., 2004) revealed that high gossypol in host cotton had a negative effect on A. gossypii. This issue was further studied by (Lukefahr and Houghtaling, 1969; Stipanovic et al., 2008). They reported that higher gossypol concentrations were required to reduce survival and pupal weights and increase days-to-pupation for larvae of Heliothis virescens larvae. On the other hand, both cotton cultivar and generation significantly affected 
the fitness of the whitefly (Guo et al., 2013). Finally, the comparison of the effect gossypol on different cotton leafworm stages is important for the development of an integrated pest management program of the S. littoralis by using plant secondary metabolic compounds.

\section{Conclusion}

The cotton leafworm, Spodoptera littoralis (Boisduval) (Lepidoptera: Noctuidae) is an important pest of numerous crops, which causes economic damage in Egypt. The failure of chemical measures to control this insect has shifted the emphasis toward the effective implementation of an integrated pest management (IPM) program. So, this study focused on secondary metabolic plant compounds (e.g., gossypol). The results of this study indicate that high gossypol could increase direct larval mortality, extend the duration of the larval stage, and thereby increase the lifespan of subsequent generations with reduced fecundity. All these factors would enhance the control of S. littoralis.

\section{References}

Abivardi, C, Benz, G. (1984). Tests with extracts of 21 medicinal plants for antifeedant activity against larvae of Pieris Brassicae L. (Lep Pieridae). Mitteil. Sweizer. Entomol. Gesell., 57:383-392

A.O.A.C. (1984). Official methods of Analysis of the Association of official Analytical chemists 14 edition edited by S. Williams. A.O.A.C. [NC. Arlington, Virginia, USA.

Boatner, CH. (1948). Pigments of cottonseed in cottonseed and cottonseed products Their chemistry and chemical Technology (A.E. Bailey, ed), In: Wiley (inter science) New York.

Cai, QN, Zhang, QW, Cheo, M. (2004). Contribution of indole alkaloids to Sitobion avenae (F.) resistance in wheat. J. Appl. Entomol., 128:517-521.

Guo, YJ, Wu, G, Wan, HF. (2013). Effects of high-gossypol cotton on the development and reproduction of Bemisia tabaci (Hemiptera: Aleyrodidae) MEAM $_{1}$ cryptic species. J. Econ. Entomol., 106:1379-1385.

Duncan, DB. (1955). Multiple rang and multiple F test. Biometerics, 11:1-42.

Du, L, Ge, F, Zhu, S, Parajulee, M. (2004). Effect of cotton cultivar on development and reproduction of Aphis gossypii (Homoptera: Aphididae) and its predator Propylaea japonica (Coleoptera: Coccinellidae). J. Econ. Entomol., 97:1278-1283.

Haijing, G, Wenjing, L, Yuansen, C, Hui, C, Yang, Z, Wenping, X, Limong, T. (2017). 5,- EpiSPA-6952A, a new insecticidal 24-membered macrolide produced by treptomyces diastatochronogenes SSPRC-11339. Natural Product. Res., 16:1-6.

Kay, RI, Noble, MR, Twine, HP. (1979). The effect of gossypol in artificial diet on the growth and development of Heliothis punctigera, Wallengren and $\mathrm{H}$. armigera, Wner (Lepidoptera: Noctuidae). J. Aust. ent. Soc., 18:229-212.

Lukefahr, MJ, Houghtaling, EJ. (1969). Resistance of cotton strains with high gossypol content to Heliothis spp. J. Econ. Entomol., 62:588-591. 
Meisner, J, Ishaaya, I, Archer, KRS, Zur, M. (1978). Gossypol inhibits protease and amylase activity Spodoptera littoralis larvae. Ann. Entomol. Sci. Am., 71:5-8.

Meng, Y, Nathalie, V, Hao, X, Lingfei, H, Ted CJT, Matthias, E. (2018). An herbivore-induced plant volatile reduces parasitoid attraction by changing the smell of caterpillars. Sci. Adv., 4: 4767.

Stipanovic, RD, López, JD, Dowd, MK, Puckhaber, LS, Duke, SE. (2008). Effect of racemic, (+)and (-)-gossypol on survival and development of Heliothis virescens larvae. Environ. Entomol., 37:1081-1085.

Wu, G, Chen, J, Ge, F, Sun, YC. (2007). Response of successive three senerations of cotton bollworm, Helicoverpa armigeraHübner fed on cotton bolls, under elevated $\mathrm{CO}_{2}$. J. Environ. Sci., 19:1318-1325.

Wu, G, Guo, YJ, Wan, HF, Xiao, WN. (2010). Responses of three successive generations of beet armyworm, Spodoptera exigua, fed exclusively on different levels of gossypol in cotton leaves. J. Insect. Sci., 10:165.

How to cite this article: Seham Mansour Ismail, Responses of Multiple Generations of Spodoptera Littoralis Feeding on Gossypol. International Journal of Advanced Biological and Biomedical Research, 2020, 8(3), 314-320. Link: http://www.ijabbr.com/article 38311.html 